\title{
The Utilizing of Three-step Interview in Improving Speaking Ability
}

\author{
Sri Hariati Mustari ${ }^{1, a}$ \\ ${ }^{1}$ Instute of Political Social Sciences 17-8-1945 of Makassar, Goverment Sciences, 90231, Indonesia \\ a srimustari@gmail.com \\ ${ }^{*}$ Corresponding Author \\ Whatsapp Number [+62-8114130593]
}

How to Cite : Mustari, S., H. (2019). The Utilizing of Three-step Interview in Improving Speaking Ability. International Journal for Educational and Vocational Studies, 1 (5), 473-478

\section{ARTICLE HISTORY}

Received: 17 June 2019

Revised: 28 July 2019

Accepted: 26 August 2019

\section{KEYWORDS}

Speaking Ability;

Three-Step Interview Technique;

\section{ABSTRACT}

This study was conducted to solve students' problem in speaking especially the students never practiced to speak each other. The researcher applied the three-step interview technique in improving their speaking ability. The instruments were speaking test, observation sheet and questionnaire. The researcher applied Classroom Action Research. It consisted of two cycles. Each cycle consisted four meetings and four steps. The steps included plan, action, observation, and reflection. The result of the research in the first cycle showed that the students' achievement and performance were so low. It could be seen from the students' score in the first cycle was 2.74. the highest score in the first cycle was 4 which were acquired by three students but the highest score at the end of the second cycle was 5.3 which was acquired by 4 students. The lowest score in the first cycle was 1.7 which acquired by one student and the lowest score in the second cycle was 3.3 which was acquired by four students. Based on the data, the researcher concluded that three-step interview technique could increase the students' ability in speaking. This technique had proven that three-step interview technique was a successful technique to help students in speaking.

\section{INTRODUCTION}

Oral communication is a process between speakers and listeners, involving the productive skill of speaking and the receptive skill of understanding (Byrne, 1984). Both the speakers and the listeners have positive function to perform. The speakers has encode the message to be conveyed and appropriate language while the listeners (no less actively has to decode or interpret) the message. When two people are engaged in talking to each other, we can be fairly sure that they are during so far reason (Harmer, 1983). When one of these people speaks, he or she can probably make the following generalization:

She or he wants to speak: what is used here in general way to someone. Speaking maybe forced on him or her in some way, but we can still say that he wants or intends to speak; otherwise he would keep silent.

He or she has some communicated purpose; speakers say things because they want something happen as a result of word that they say.

He or she selects from the language store, the speaker has an infinite capacity to create new sentences if they are a native speaker.

There are seven principles for designing speaking techniques (Brown, 2007). As the techniques that cover spectrum of learner needs, from language based focus on accuracy to message; Provide intrinsically motivation technique; Encourage the use of authentic language in meaningful context; Provide appropriate feedback and correction; Capitalize on the natural link between speaking and listening; Give students opportunities to initiated oral communication; and Encourage the development of speaking strategies.

There are six types of classroom speaking performance that students are expected to carry out in the classroom (Walker et al, 1997). There are Imitative, Intensive, Responsive, Transactional (dialogue), Interpersonal (dialogue), and Extensive (monologue).

There are at least four principles for teaching speaking (Nunan, 2003). First, give students practice with both fluency and accuracy; then Provide opportunities for students to talk by using group work or pair work, and limiting teacher talk; and plan speaking tasks that involve 
negotiation for meaning; the last, design classroom activities that involve guidance and practice in both transactional and interactional speaking.

Problems that students faced in speaking learning process are various, one of them is students thought that speaking is very difficult because they had to speak by using foreign language which is very different from their own language.Learning to talk in the foreign language is often considered being one of the most difficult aspects of language learning for the teacher to help the students (Brown and Yule 1983). The students find the difficulty to say something because of lack of vocabulary, problem to pronounce the words, less of confidence when speaking. Then they also thought too much about the grammar.

The problems are affected by some factors which are the teachers never asked the students to practice to speak English in the class, the teachers also never applied a good technique to the students in speaking in the class, the environment did not support to speak frequently, the facilities in their school are not adequate. Those problems caused in English lesson specially in speaking. So, the teachers had togive a good technique and some motivations to the students to encourage students' interest in learning speaking. However, the most particular thing was from the students themselves.

Three-Step Interview is a learning model in which consist of three or four members of students. In this method, students work in pairs, first one way, than the other. Students each share with the group information they learned in the interview (Orr, 2006).

There are three steps in this technique. First, students from two pairs within their teams of three and conduct a one-way interview in pairs. Second, students reverse roles: interviewers become the interviewees. The last, students round robin: each student takes a turn sharing information learned in the interview (Orr, 2006)

The characteristics of this technique are; Equal participation, all participate, individual participate, individual accountability, one-half of class taking at a time. In three-step interview each person must produce and receive language, there is individual accountability for speaking, because in the third step each students shares what he or she has said, and for the first two steps, students interact in pairs, so one-half rather than one-fourth of the class is involved in language production at any one time (Orr, 2006).

\section{METHODS}

This research used Classroom Action Research (CAR). The main proposes of Classroom Action Research are to identify and to solve the students' problem in the class (Rapoport in Hopkins, 1993: 44). Besides, Classroom Action Research is to study a real situation with a view to improve the quality of actions and result within it (Schmuck, 1996).

\subsection{Research Setting and Research Subject}

This research was taken place of the second year students of MA Alauddin Paopao. The class chosen by the researcher was class XI. This research consisted of two cycles. Each cycle consisted of four meetings. This research aimed to solve the students problem when speaking by using the three-step interview technique of the second years students of MA Madani Alauddin Paopao consisted of 30 students.

\subsection{Research Preparation and Implementation}

The researcher prepared lesson plans, guidelines of observation, and questionnaire. Generally the procedures of the action in each cycle of this research were,

The students gave warming up before starting the materials. The students gave warming up can be game, quiz or speaking activity. The students were guided to follow activity in the classroom. The activity was able to support student understanding in materials. As evaluation, the student was given speaking test.

\subsection{Technique of Collecting Data}

The techniques that researcher used to get a valid data were:

\section{a. Planning}

Researcher made a good planning before doing research in the field. After the researcher obtained data about their students' problems in speaking, the researcher gave them treatment to improve their ability and to overcome their problems in speaking.

b. Action

Researcher gave them treatment to improve their speaking ability and to overcome their problems. The treatment that the researcher conducted was three-step interview technique.

\section{c. Observation}

Observation is observing the event, movement or process (Arikunto, 2011). Purpose of the observation was to describe and setting up the lessons, activities, the persons that involve in the activities and the meaning of the event from their point of view that shown in that mentoring.

\section{d. Evaluation and reflection}

In evaluation and reflection, the researcher focused on the indicators that had achieved and had not achieved. After analyzing the indicator, the researcher focused on the indicator that had not achieved yet. The researcher looked for the problem solving to achieve the indicators. In evaluation and reflection also the researcher thought the planning, acting in the next cycles.

\subsection{Researcher Position}

The researcher was an instructor during the teaching process goes on. Then, the teacher was the collaborator who observe the teaching and learning process in the class. 


\subsection{Instrument}

a. Speaking Test

In this cased in speaking test was interview.

b. Guidelines of Observation

The researcher observed what happen in the classroom, what the students did in the classroom. Also the weakness of the learning process. She wrote down all the students' activities during the teaching and learning process. There were some aspects observed in the teaching and learning process, namely the students' learning activities, creativities, feeling happy, and interactions.

\subsection{Technique of Data Analysis}

The quantitative data were obtained from the result of the test (achievement data) that was carried out at the end of the cycles. In terms of the achievement data, the analysis is as follows:

\subsubsection{Comparative Descriptive Analyzing}

The students' achievements were analyzed by using comparative descriptive analyzing. This analyzing compared the students' achievement among the cycle and the indicator that would be achieved.

\subsubsection{Statistic Analyzing}

Krashen in Haunan, (2013) suggests three terms to point out in case of measuring the students' speaking ability. They are accuracy, fluency, and comprehensibility. Accuracy has something to do with the students pronunciation, fluency is a case notes in line with the speeches that produced by the students, while accuracy is something to do with the sentence produced by the students, whether it can be understood or not.

The term of accuracy is a kind of giving point of the students speaking skill in term of its accent, pronunciation, and any lexical grammar errors.

The term of fluency has something to do with the way of speaker makes any effort searching words, pauses does in line with the question asked by the examiner, minor grammatical and lexical item.

The term of comprehensibility has something to do with the way of speaker makes any test taker get the examiner understand to the speech produced.

\subsubsection{Scoring the students correct answer}

Scoring: Students' correct answers

Total number of items

\subsubsection{Classifying the score of students}

Classifying the score of students by using following scale.

\begin{tabular}{lcc}
\hline No. & Scale & Classification \\
\hline 1 & $5.6-6.0$ & Excellent \\
\hline 2 & $4.6-5.5$ & Very Good \\
\hline 3 & $3.6-4.5$ & Good \\
\hline 4 & $2.6-3.5$ & Fair \\
\hline 5 & $1.6-2.5$ & Poor \\
\hline 6 & $0.0-1.5$ & Very Poor \\
\hline
\end{tabular}

2.6.5 Calculating the rate percentage of the students score

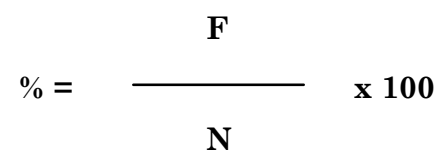

Where:

$\% \quad$ : Percentage

F : Frequency

$\mathrm{N} \quad$ : The total number of the (students).

\subsubsection{The mean score of the students' achievement}

$$
\bar{x}=\frac{\sum x}{N}
$$

Where:

$\overline{\mathrm{x}} \quad=$ Mean Score

$\sum X=$ The sum of all scores

$\mathbf{N}=$ The number of subject (students)

\section{RESULTS AND DISCUSSION}

\subsection{The First cycle}

\subsubsection{Plan}

To conduct this research, all required materials were prepared first. Some things that the researcher should prepare and run in this research were lesson plan, speaking test, recorder, observation sheet and questionnaire. All the materials and the activities had to be suitable with the lesson plan.

During the teaching and learning process, the collaborator observed the students' learning activities, interaction between teacher and students, situation and condition in class and media that researcher used in class. To observe them, collaborator would use observation sheet.

\subsubsection{Action}

Based on the planning, three-step interview technique was applied during the teaching and learning process. The 
procedures were; first entering the class and giving greeting to all the students. Second, checking the attendance list. Third, having conversation with the students about their holiday. Fourth, introducing the three-step interview technique. Fifth, applying the three-step interview technique. The last, having conversation in pair. Those procedure applied for four meeting but students' given different topic each meeting. Then in the fourth meeting of this cycle, the researcher gave assesment to measure their achievement of the lesson. The assesment criteria was fluency, accuracy and comprehensibility.

\subsubsection{Observation}

There were four aspects and there were fifteen indicators in teaching and learning process in the observation sheet. The first aspect was learning activities and the indicators of the first aspects were doing their assignments based on the teachers' instruction, asking question to their teacher if there was an instruction which was not clear, giving comments and suggestions about their friends' job, presenting their discussion result without being appointed by the teacher, discussing and working together with their friends in doing their assignments and doing assignments from their teacher well. The second aspects was creativities and the indicators of the second aspect is showing their curiosity by asking question to their teacher and friends, exploring their ideas and thinking and were not hopeless for looking for answer using books or asking to their friends. The third aspects was feeling happiness and the indicators of the third aspect was looking happy in learning process and not feeling sleepy during the teaching and learning process. The last aspect was interaction and the indicators of the last aspect were discussing with their teacher, discussing with their students and working together with their friends (Sukirman in Wahyudi, 2013).

This was considered a good improvement of the students' achievement in speaking. Although the score showed a good achievement of the students but, only some students who receieved a good classification in accuracy and fluency criteria then, there was not student who achieved excellent and very good classification in the first cycle.

For more detail, students accuracy described as 5 students (19.6\%) achieved good score and 9 students (30.7\%) achieved fair score. 12 students (46.1\%) achieved poor score and 1 student (3.84\%)chieved very poor score. While in first cycle there was no students achieved Excellent and very good score. Then for fluency, there were no student who achieved excellent and very good score. 10 (38.4\%) students achieved good score and 11 (42.3\%) students achieved fair score. 4 (15.3\%) students achieved poor and no one students achieved very poor score. And for Comprehensibility, there were 1 (3.84\%) students achieved very good score. 12 (46.1\%) students achieved good score. 10 (38.4\%) students achieved fair score and 4 (15.3\%) students achieved poor score. There was none achieved excellent.
From all the previous data, it concluded that in the first cycle there were improvements in both the students' understanding of the material and the students' participation in the class. Nevertheless, there were some students still unsatisfy because they were received bad scores. Therefore, the researcher decided to improve the students' achievements of speaking ability in the next cycle, the second cycle.

\subsubsection{Reflection}

Based on the data of the result of the observation and the score of the test was still unsatisfying of their score, the researcher needed to do stabilization in the second cycle especially the students' activities in the class and the students' speaking ability through three-step interview technique. In the next cycle, the researcher used the different topic because the researcher would like make the students more interested in teaching-learning process, so the students' achievement would be better than in the first cycle.

\subsection{The Second Cycle}

\subsubsection{Plan}

The planning for the first and second cycle were the same because there were are lesson plan, speaking test, recorder, guidelines of observation, and questionnaire. The stabilization of the action in this part were; reviewing the speaking ability. After that, motivating the students who were afraid and shy in giving question. Also, the researcher has to focus on the students who still did not understand the material. Then, the researcher gave vocabulary list to increase the students' vocabulary. Then, the researcher gave different test in the second cycle.

\subsubsection{Action}

Mostly the acting in the first cycle and the second cycle were just the same, but the researcher focused on the stabilizations of the first cycle to decrease the weaknesses in the first cycle.

The researcher reexplained the three-step interview technique. Then, the researcher applied the three-step interview technique. In the first, second and third meeting, the researcher gave students some topics to be discussed. And in the fourth meeting, the researcher re-assess students' accuracy, fluency and comprehensibility.

\subsubsection{Observation}

Based on the table of observation sheet and result of observation sheet in the second cycle, there were some indicators that made the teacher more happy than in the first cycle because the score of the students in observation sheet were highest specifically than first cycle. It was found that $92,3 \%$ of the students did their assignments based on 
the teachers' instruction. Next $92,3 \%$ of the students asked questions with their teacher which was not clear. Then, 76, $9 \%$ of the students gave comments and suggestions. Then, 73,7 \% presenting their discussion without appointing by their teacher. Then, $84,6 \%$ of the students discussed and worked together. Next, 69, $2 \%$ of the students did their assignment from their team. 80, $7 \%$ of the students were shown their curiousty. Then, $69,0 \%$ of the students explored their idea. Then, 84, $4 \%$ thought and not hopeless looking for answer by using books or asking to their friends. Then,92, $3 \%$ of the students looked happy in learning process. $88,4 \%$ of the students did not feel sleepy. Next, 65, $3 \%$ of the students discussed with their teacher. Than, 69, $2 \%$ of the students discussed with their friend. The last, 96, $1 \%$ of the students worked together with their friends.

All indicators in the second cycle achieved high improvement than first cycle by looking the percentage of each cycle. Besides observing whether three-step interview technique could overcome the students' problems and improve the students' speaking ability, the researcher also gave the students a competence test to know the students' achievements of the material during the teaching and learning process.

The score of competence test in the second cycle showed that the scores of the students increased. Students' mean score in the competence test after the first cycle was 2.74 then increased in the second cycle became 5, 63. This is considered a good improvement of the students' achievement. There were three students who achieved 3, 3 score. Then, there were six students who achieved 3,7 score. Next, there were six students who achieved 4 score. Then, there were also six students who achieved 4, 3 score. Next, there were four students who achieved 5, 3 score.

\subsubsection{Reflection}

The students' score at the end of this research increased totally. The researcher was success in received the success indicators in the class. The students' mean score in the first cycle was 2. 74 and the students' mean score in the second cycle was 5.63 The highest score in the first cycle was 4 which were acquired by three students but the highest score at the end of the second cycle was 5.3 which was acquired by 4 students. The lowest score in the first cycle was 1.7 which acquired by one student and the lowest score in the second cycle was 3.3 which was acquired by four students. Besides the increase in students' scores in the second cycle, the students' participation and students' interaction between teacher and students showed a high upgrading also than in the first cycle.

\subsection{Questionairre}

Based on the result questionnaire, the date showed that the responses of the students during teaching and learning process were very good. The table showed that there were only five students who achieved fair score, eighteen students who received good score and three students who caught very good score. All students gave positive responds by giving fair criteria, good criteria and very good criteria in teaching and learning process in the class. There was not student who dissatisfied during learning and teaching process.

\section{CONCLUSION}

The research has proven that three-step interview technique can increase the speaking ability of the students. The mean test score from 2.74 in the first cycle increased to 5.63 in the second cycle. The students more interested to know about speaking activity after the researcher applied three-step interview. Besides, the students gave positive responses also by giving accuracy criteria, fluency criteria and comprehensibility criteria good during teaching and learning process in the class.

Based on the observation, it is found that the students' performance when they were speaking had achievement likes, looking happy when speaking, showing their curiosity when speak and felt shy to speak was avoided. The most important, although English is the second language for the students but they can avoid distracting, for example use umm or aa..aa. when speaking.

The three step interview technique is the good technique to stimulate and improve the students' speaking. It is not only small number of students but also the large number of students. It has many activities in implementing the technique, such as find your partner, small group, talking each other and same different. It is method has the students more active to speak among the students to students, no students to teacher/lecturer. The teacher as designer and organizer is like director in a movie, to the design the structure of the class, to make out the content of the interaction, and to keep the learning process flowing smoothly and effectively (Brown, 2001,p . 167).

\section{REFERENCES}

Arikunto, S. (2011). Prosedur Penelitian Suatu Pendekatan Praktik. Jakarta: Rineka Cipta.

Brown, G and Yule. G. (1983). Teaching the Spoken Language. Cambridge: Cambridge University press.

Brown, G and Yule. G. (2001). Principles of Language Learning and Teaching. San Francisco: Addison Wesley Longman, inc.

Byrne, D. (1984). Teaching Oral English. New York: Longman Inc.

Harmer, J. (1983). How to Teach English. London: Longman Press.

Haunan, R. P. (2013). Improving Speaking Ability of the Second Year Students at MTs Madani Alauddin Pao-Pao Through Describing Idol Picture. Thesis. Makassar: UIN Alauddin.

Hopkins, David. (1993). A Teacher's Guide to Classroom Research. Philadelphia: Open University Press. 
Orr, J. K. (2006). Growing Up with English. New York: Office of English Language Programs United States Department of State Washington, DC. 